\title{
Laboratory, in sacco and in vivo assessment of various treatment conditions affecting the sulphurizing of wheat straw
}

\author{
JW Lambrechts, WA Smith, J Sales \\ Dept of Animal Sciences, University of Stellenbosch, Stellenbosch 7599, Republic of South Atrica
}

The objective of this study was to examine the effects of treatment time, $\mathrm{SO}_{2}$ levels, moisture levels and temperature on laboratory assessments, in sacco degradabilities and in vivo digestibilities of untreated and ammonia $\left(\mathrm{NH}_{3}\right)$ treated wheat straw.

Wheat straw and gas ammoniated $(3 \% \mathrm{w} / \mathrm{w})$ wheat straw were treated with $\mathrm{SO}_{2}$ at 1,2 or $3 \%$ dry matter (DM) for $10,20,30$ or 40 days at 20,40 or $60^{\circ} \mathrm{C}$ and 10,35 or $60 \%$ moisture according to a factorial experimental design. Treated straw was analyzed for acid detergent fibre (ADF) and neutral detergent fibre (NDF). Means were compared according to least significant differences (LSD). The six treatments with lowest ADF and NDF contents were also compared in sacco with $\mathrm{NH}_{3}$-treated and untreated wheat straw for effective degradability of dry matter (DM), ADF and NDF according to the method described by Orskov and McDonald (1979, J Agric Sci, 92, 499503). The two $\mathrm{SO}_{2}$ treatments with highest in sacco effective degradabilities, untreated and $\mathrm{NH}_{3}$ treated wheat straw were then included in total mixed diets ( $40 \% \mathrm{DM})$ and compared in an in vivo digestibility trial with 5 sheep per treatment.

Lowest NDF values for ammoniated straw were recorded with the $2 \% \mathrm{SO}_{2}$ treatment $(\mathrm{P}<0.05)$ at all moisture and temperature levels.
Untreated straw responded most effectively to $3 \% \mathrm{SO}_{2}$ treatment $(\mathrm{P}<0.05)$ at the highest temperature $\left(60^{\circ} \mathrm{C}\right)$ and highest moisture level $(60 \%)$. Although some treatments decreased ADF values $(P<0.05)$, the effects were small and no clear trend was observed.

In sacco effective degradability of DM was higher $(\mathrm{P}<0.05)$ for $\mathrm{SO}_{2}$ and $\mathrm{NH}_{3}$ treated straw compared with untreated straw. Best results were achieved with $3 \% \mathrm{SO}_{2}$ treatment at $60 \%$ moisture and $40^{\circ} \mathrm{C}$ for 30 days $(41.24$ vs $30.62 \%$ for untreated straw at a rumen outflow rate of $0.05 / h$ ). NDF and ADF degradabilities did not follow the same trend found with DM degradabilities.

The DM digestibilites of total diets containing $40 \%$ untreated straw, $\mathrm{NH}_{3}$ treated straw and two $\mathrm{SO}_{2}$ treated straws (a : $3 \% \mathrm{SO}_{2}, 60 \%$ moisture, $40^{\circ} \mathrm{C}, 30$ days ; $b$ : $3 \% \mathrm{SO}_{2}, 60 \%$ moisture, $60^{\circ} \mathrm{C}, 10$ days) did not differ $(71.61$, $71.09,72.76$ and $72.92 \%$ ). Organic matter (OM), NDF and ADF digestibilities also did not differ amongst treatments.

Promising results regarding the $\mathrm{SO}_{2}$ treatment of wheat straw were found with laboratory analysis and in sacco evaluations. The same trend was not found when $40 \%$ treated straw was included in total diets in an in vivo digestibility trial. 